\title{
Climate smart agricultural technologies in rice-wheat water stressed regions of Punjab, India- A review
}

\author{
Jhanvi Saini* \\ University institute of Engineering and Technology, Panjab University, Chandigarh, India \\ Rajan Bhatt \\ Scientist (Soil Science), Regional Research Station, Kapurthala, Punjab Agricultural \\ University, Ludhiana- 141004 (Punjab), India
}

*Corresponding author. E-mail:jhanvisaini12345@icloud.com

\begin{abstract}
Intensively cultivated rice-wheat cropping sequence of Punjab, India responsible for many sustainability issues viz. declining underground water, declining soil health, arising micronutrient deficiencies etc. Around $1.3 \mathrm{M}$ ha-m additional withdrawal of water from the ground is being taken place annually in Punjab and mainly it is used for the rice crop which is not a traditional crop of the region. Puddling, seepage and percolation losses are the main sources of water loss from the rice based cropping systems in the Indo-Gangetic plains (IGPs) and many Resource Conservation Technologies (RCTs) have been recommended for water saving. The real water saving techniques are those which hinder the water from going into those sinks from where it cannot be reused (Evaporation, E) and diverted greater fraction of water of ET toward transpiration $(\mathrm{T})$ which is desired as greater transpiration, greater the inflow of water and nutrients andwhich ultimately increase the grain yield with the lesser consumption of irrigation water as interval in between two irrigation increases, which further increase the water productivity. Among different RCTs, short duration crop varieties and delaying transplanting time are the real water saving techniques for the regions where water table is already declining down, however other RCTs may be suitable for the regions facing water logging problems as these cut down the drainage losses and these energy saving rather than water saving techniques.
\end{abstract}

Keywords: ET, IGPs, Puddling, Rice, RCTs, Water saving

\section{INTRODUCTION}

In Punjab, rice-wheat cropping sequence intensively cultivated which is responsible for many sustainability issues as declining water table, declining soil health, arising micro-nutrient deficiencies etc. (Arora et al., 2008; Arora et al., 2011; Bhatt et al., 2018 a,b,c ; Hossain and Bhatt, 2019; Bhatt and Kukal, 2018; Bhatt and Singh, 2018; Sur et al., 1981; Jalota and Arora, 2002). Rice-an important staple foods for $>50 \%$ world's population (IRRI, 2006) and influences the livelihoods of farmers. Approximately 154 million ha of rice was harvested worldwide during 2010 , of which $88 \%$ of the global rice harvested was in Asia- of which $31 \%$ harvested were harvested in Southeast Asia. Irrigated rice has higher land productivity than rainfed rice (Wallace and Gregory, 2002). More than $80 \%$ of freshwater resources are used for irrigation purposes, $50 \%$ of it further used only in rice (Dawe, 2005). In agriculture, global demand for water will increase over time with increasing population, rising incomes, and change in dietary

\section{Article Info}

https://doi.org/

10.31018/jans.v11i3.2149

Received: July 21, 2019

Revised: September 3, 2019

Accepted: September 6, 2019

\section{How to Cite}

Saini, J. and Bhatt, R. (2019). Climate smart agricultural technologies in rice-wheat water stressed regions of Punjab, India- A review. Journal of Applied and Natural Science, 11 (3): 698- 703 https:// doi.org/10.31018/jans.v11 i3.2149 preferences (Bhatt et al., 2018 a,b,c,; Bhatt et al., 2016; Bhatt and Kukal, 2017). By time, industrial and urban water needs increased, which further intensify the water competition and water scarcity. Being largest groundwater user, India consumed $>25 \%$ of the global water use (Tyagi et al., 2012), which further needs attention. "GRACE"- NASA's gravity mapping satellite tracks that in North India about in an area of $440,000 \mathrm{~km}^{2}$ under-ground water declined with rate of $30 \mathrm{~cm}$ year ${ }^{-1}$ which outcome in the loss of $4 \mathrm{~cm}$ of raw ground water (Soni, 2012).

Must use input for agriculture is irrigation water and it's timely and assured availability significantly affects both land and water productivity in any region. For supplementing irrigation needs $>80$ $90 \%$ of the underground water is used, which further effected by the soil type and agro-climatic conditions. Further, water usage is almost nil in the humid regions as compared to that of the arid and semi-arid region. During 2010, groundwater demand soared from $10-20 \mathrm{~km}^{3}$ before 1950 to $240-260 \mathrm{~km}^{3}$ by the turn of the century in Indian 
Saini, J. and Bhatt, R. / J. Appl. \& Nat. Sci. 11(3): 698- 703 (2019)

sub-continent (Prihar et al., 2010). Punjab and Haryana often referred to as the 'Food Bowl' of the country, as provides $>50 \%$ of the national rice production (Dhillon et al., 2010). To improve the declining water productivity in the region, several resource conservation technologies (RCTs) being recommended for efficient water management (Humphreys et al., 2010). Hira et al., 1998 delineates the rising water stressed conditions as current annual water deficit of $\sim 1.27 \mathrm{M}$ ha-m (Jain and Kumar, 2007, Bhatt et al., 2016). During the last forty years, water demand jumped from 2.76 to $4.76 \mathrm{M}$ ha-m (Minhas et al., 2010). Throughout the India, area irrigated with underground water has amplified to 6-times from 1950-51 to 2005-06 (Tyagi et al., 2012) as ground water use soared from $10-20 \mathrm{~km}^{3}$ to $240-260 \mathrm{~km}^{3}$ during the same period. The water table is declining in the region year per year, as a result of which a number of different RCTs have been recommended, but we will have to pick the exact ones which are suitable to our conditions i.e not cutting down the drainage in the water scarce regions because that water could be reused for meeting our irrigation requirements (short duration crop varieties and delaying transplanting time), while in the water logged conditions, cutting the drainage losses are desirable as that regions are already suffering from the problem of waterlogging and salinity (Bhatt et al., $2018 a, b, c)$. The objective of the present review was to look into detail performance of each RCTs regarding their role for improving both land and water productivity with best and efficient use of water under texturally divergent soils and under different agro-climatic conditions.

Role of laser leveler in water saving: Flood irrigation is most adopted practice in rice-wheat cropping system in the IGP because of which a significant amount of water lost $(10-25 \%)$ because of uneven fields (Kahlown et al.,2002) which further results in poor resource use efficiency (Jat et al., 2009). Frequent dikes and ditches in the fields always results in lower water productivity as uneven fields results in uneven distribution of the irrigation water, thus more water used for producing fixed amounts of grains. According to Jat et al., (2009) laser leveling results in improved crop stand because of uniform distribution of water along with improved crop productivity and lower labour requirement. LL improved the farm income by improving system productivity to $7 \%$ and by saving irrigation water upto $14 \%$ in rice and upto $13 \%$ in wheat (Jat et al., 2009). According to Jat et al (2011) LL helps in saving of $31.26 \%$ water in flat planting and $22.56 \%$ in raised beds, however in western UP, LL results in reduction of $33 \%$ in water which further improved application efficiency from $60 \%$ to $88 \%$ and distribution efficiency from $80 \%$ to $92 \%$. As a result, irrigation water productivity ( $\mathrm{kg}$ grain $\mathrm{m}^{-3}$ ) improved upto
$24.4 \%$ and $19.6 \%$ respectively in rice and wheat. Laser leveling also improved the nutrient use efficiency by $110 \%, 100 \%$ and $228 \%$ for nitrogen, phosphorus and potassium. Along-with improving water and nutrient use efficiency, laser leveling also enhanced weed control efficiency and improved crop land productivity. Thus, LL cut down the water requirements, increases water productivity but another question associated with LL is that it cuts down the water recharge rate which is not desirable particularly in the water stressed areas. The performance of laser leveler in differently textured soils given by different authors is being given in given in Table 1 .

Role of Direct Seeded Rice (DSR) in water saving: As reported by many scientists that puddling deteriorates the soil structure (Kukal et al., $2003 a, b)$. Secondly it also causes problems in the establishment of the succeeding crop viz. wheat. Water input in rice must be reduced by one or other way. In Asia, rice is transplanted into flooded puddled soils where soil textured already deteriorated because of puddling, forming plough pan which further restricted the root growth of next upland aerobic crop viz. wheat. For puddling, land prepared by soaking/flooding with good quality irrigation water, breaking the aggregates and forming the plough pan following the stroke's law. Even then, large water losses are there by seepage, percolation, and evaporation, generally resulting in lower irrigation water productivity (Bouman and Tuong, 2001). Direct seeded rice come out with a hope as no puddling operations are required here which further means lower use of irrigation water and good soil health, which is free from the plough pan and offers no restrictions to the wheat roots (Yadav et al., 2015). Mainly DSR comprised of three types viz. DSR-CT (DSRConventionally tilled), DSR-ZT (DSR-zero tilled) and DSR-P (Wet DSR) (Bhatt and Kukal, 2017), last one required puddling and the pre-germinated rice seeds dropped using the drum seeder in lines. Detailed reviewed work highlighted that DSR is not universally applicable, weather it is a site specific technology and its performance varied as the soil texture varied (Bhatt and Kukal, 2015, Jat et al., 2009). DSR proves to be a great failure in light textured soils because of significantly higher weed seeds and severe iron deficiency (Bhatt and Kukal, 2017). Because of no puddling, water drained away frequently and as a result more no. of irrigation water applied which further results in lower irrigation water poroductivity (Bhatt and Kukal, 2018). Gupta and Seth, 2007 also reported varied performance and claimed a possible reason for this differential performance in northwestern versus eastern IGP is lower annual rainfall in the former $(400-750 \mathrm{~mm})$ than in the later (1000-1500 mm).

Bhuiyan et al., (1995) and Hukkeri and Sharma 
(1980) reported higher irrigation water use which could be due to (1) a longer crop growth period in the main field in DSR than in PTR (Rashid et al., 2009) and (2) higher percolation losses in DSR (Sudhir-Yadav et al., 2011a). Further, under clay loam soil in Punjab, Sudhir-Yadav et al., (2011b) observed substantial saving in irrigation water with statistically land productivity with both methods of establishment's viz. DSR and PTR under intermittent irrigation. DSR plants being sown directly into the soil established earlier than the other method but required more water because of higher seepage losses as there is no plough or puddle layer (Tuong et al.,2000). Though at some places initially some irrigation water saving observed because of no puddling but on the long run total irrigation water use claimed to be higher in the DSR than PTR. Rainfall pattern and time of occurrence are other major deciding factors in irrigation Bouman productivity of rice has been reported to be higher in DSR than PTR (Sudhir-Yadav et al., 2011b, Humphreys et al., 2010). Bouman and Tuong (2001) observed that DSR, results in some yield losses because of severe competition with weeds and severe iron deficiency. Hence, number of drops used to produce per $\mathrm{kg}$ of water assumed to be the best parameters for ranking a particular technology under a particular soil texture in terms of their effective use of irrigation water and grain production (Tuong 1999).

Land productivity in DSR generally reported to be on the inferior side than the puddle sites principally owing to poor crop stand and high weed infestation (Singh et al., 2005). Micronutrient deficiencies such as $\mathrm{Zn}$ and $\mathrm{Fe}$, due to imbalanced N fertilization and high infiltration rates in DSR, are of major concern (Gao et al., 2006). Production costs reported to be higher in DSR because higher required power for irrigations (Rao et al., 2007). Because of new technology and absence of nursery raising, seedling uprooting, and transplanting, farmers are adopting this technology. But our recommendation here is to first consider your soil type as only medium to heavy textured soils re- spond to DSR while in light textured soils it is not economical to go with DSR.

Role of permanent beds in water saving: Bed Planting is also known to be a very important RCT for saving water upto $20-30 \%$, has been first tried for wheat on the pattern of Mexico and later for rice (Singh et al.,2005). Beds solved of the problem of aeration stress in wheat particularly in the heavy less permeable soils. It also reduces the lodging due to lesser water in wheat and increase in thickness of basal internodes. Beds seems to improve water productivity as water use efficiency is always higher in furrows for both rice and which further reflected in the reported higher water. In the IGP, wheat grows successfully on raised beds, with similar or higher yields and about $18 \%$ to 30 $50 \%$ less irrigation water than conventional tillage on the flat (Singh et al., 2005) but usually these beds are destroyed after wheat for successful puddling operations for paddy establishment. Permanent beds reported to improve the soil structure and water infiltration down the profile as compared to the PTR. Humphreys et al. (2010) in their review showed that irrigation water savings for directseeded and transplanted rice on beds in the IGP varies from $12-60 \%$, but with variable effects on yield and water productivity. Higher cracking of loam in permanent beds when a full-furrow depth of irrigation was applied (Kukal et al., 2010). But at some sites, on the contrary, higher water use efficiency (WUE) was observed in bed planted crops (Brar et al., 2011). Lower irrigation water productivity with time on permanent beds reported to be because of higher bulk density in the side slopes as they were compacted due to tractor-tyre (Kukal et al., 2008). Secondly, higher beds reported to offer higher surface area for higher evaporation which further requires frequent irrigations, which further resulted in lower irrigation water productivity. Further Kukal et al (2008) reported that compaction of the side slopes of the beds during repeated reshaping increases the bulk density of the side slopes and due to natural aging of the beds, which further hinders the proliferation of the rhizo-

Table 1. Performance of laser leveler in differently textured soils.

\begin{tabular}{|c|c|c|c|c|}
\hline Scientist and year & Soil texture & State, Country & $\begin{array}{l}\text { Total Water sav- } \\
\text { ing }(\mathrm{cm})\end{array}$ & $\begin{array}{l}\text { Average percent yield } \\
\text { increase }\left(\mathrm{t} \mathrm{ha}^{-1}\right)\end{array}$ \\
\hline Jat et al.,2009 & sandy loam & Uttar Pardesh, India, & $12-14 \%$ & NS \\
\hline Jat et al.,2011 & sandy loam & Modipuram, India & $25 \%$ & $15 \%$ to $35 \%$ \\
\hline Jat et al.,2003 & -- & 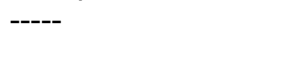 & $\begin{array}{l}49 \% \text { in wheat and } \\
31.7 \% \text { in Paddy }\end{array}$ & $6.9 \%$ in wheat \\
\hline Jat et al.,2006 & Sandy laom & & & $\begin{array}{l}7.31 \% \text { in rice and } \\
6.14 \% \text { in wheat }\end{array}$ \\
\hline Rickman, 2002 & & & & $\begin{array}{l}24 \% \text { increase in rice } \\
\text { yield }\end{array}$ \\
\hline Sattar et al.,2003 & & & & $\begin{array}{l}20.1 \% \text { increase in seed } \\
\text { cotton }\end{array}$ \\
\hline Pal et al.,2003 & & Modipuram, India & & \\
\hline Abdullaev et al.,2007 & Loamy soils & Tajikistan & $811 \mathrm{M}^{3} / \mathrm{ha}$ & $\begin{array}{l}31 \% \text { increase in cotton } \\
\text { yield }\end{array}$ \\
\hline
\end{tabular}


sphere in the $0-15 \mathrm{~cm}$, but this problem could be handled by using narrow tyres. Rice land productivity decreased by $19 \%, 45 \%$ and $59 \%$ in 2004 to 2006 against the 2003.

Role of tensiomters in water saving: Changing global climatic patterns coupled with declining surface and ground water resources (Yadav et al., 2018; Bhatt et al., 2018_a,b,c) have put agriculture on the back foot. Annually, we are extracting $>13$ Lakh ha-m of additional water from the ground which further decline the water table. In these conditions application of irrigation water as and when required is very important in improving the water productivity. Thus, tensiometers which work on the principles of soil matric potential (a force with which water is held in the soil matrix) helps us to apply water as and when required (Bhatt et al., 2014). Work done by Bhatt and Sharma (2010) showed that during the years from 20062010 , the water saving varies from 11.1 to $30.7 \%$ with almost similar yields as it avoids unnecessary supply of water and helps us to apply water as and when required in right quantity. Kukal et al (2005) reported that water saving with Tensiometer based irrigation varies from 25 to $46.1 \%$ as compared to the 2day interval irrigation (Ea-rlier practice of irrigation) and thus reported highest water productivity $\left(0.5 \mathrm{~g} \mathrm{~kg}^{-1}\right)$ as compared to 2 day interval $\left(0.34 \mathrm{~g} \mathrm{~kg}^{-1}\right)$ and continuous irrigation $\left(0.28 \mathrm{~g} \mathrm{~kg}^{-1}\right)$. Thus, tensiometer helped to increase both land as well irrigation water productivity by timely and judiciously irrigating the crops (Bhatt et al., 2016).

\section{Conclusion}

For improving both land as well as water productivity in the region, number of technologies viz. laser leveler, bed planting, direct seeded rice and tensiometer, are being recommended. But before adopting them, this needs to keep in mind that these technologies are both site and situation sensitive as one technology working in one site might be a failure at other site under other soil textural class. Therefore, utmost care is to be taken while selecting one or other RCT depending upon one's conditions for improving declined both land and water productivity on one side while practicing sustainable agriculture on the other after mitigating the adverse effects of the global warming.

\section{REFERENCES}

1. Abdullaev, I., Husan, M. U. and Jumaboev, K. (2007). Water saving and economic impacts of land levelling: The case study of cotton production in Tajikistan. Irrigation Drainage System, 21: 251-263.

2. Arora, V.K, Singh, C.B., Sidhu, A.S. and Thind, S.S. (2011). Irrigation, tillage and mulching effects on soybean yield and water productivity in relation to soil texture. Agric Water Manage., 98: 563-68.

3. Arora, V.K., Jalota, S.K. and Singh, K.B. (2008). Managing water crisis for sustainable crop productivi- ty in Punjab; an overview. J Res (PAU)., 45: 17-21.

4. Bhatt, R. and Kukal, S.S. (2015). Direct seeded rice in South Asia. In: Eric Lichtfouse (ed.) Sustainable Agriculture Reviews. 18: 217-252

5. Bhatt, R. and Kukal, S.S. (2017). Tillage and establishment method impacts on land and irrigation water productivity of wheat-rice system in North-west India. Experi Agri 53 (2): 178-201. DOI:10.1017/ SOO14479716000272.

6. Bhatt, R. and Kukal, S.S.(2018). Delineation of soil water balance in wheat-dry direct seeded rice system under conventional and zero-till conditions in semiarid Tropics. Oryza 55(4): 574-589.

7. Bhatt, R. and Sharma, M. (2010). Management of irrigation water through Tensiometer in paddy-A case study in the Kapurthala District of Punjab. Paper orally presented and Published In Proceedings of Regional workshop on Water availability and Management in Punjab organised at Panjab University, Chandigarh.199-205.

8. Bhatt, R. and Singh, P. (2018). Rice-Wheat Cropping Sequence viz-a-viz Natural Resources of Punjab, India. Ann Agric Crop Sci., 3(1): 1033.

9. Bhatt, R., Arora, S. and Chew, C.C. (2016). Improving irrigation water productivity using Tensiometers. $J$ Soil Water Conser., 15(2): 120-124.

10.Bhatt, R., Hossain, A. and Hasanuzzaman, M. (2018a). Adaptation Strategies to Mitigate the Evapotranspiration for Sustainable Crop Production: A Perspective of Rice-Wheat Cropping System. Accepted in Agronomic crops (Springer-nature Publication)

11.Bhatt, R., Hossain, A. and Singh, P. (2018b). Scientific interventions to improve land and water productivity for climate smart agriculture in South-Asia. Accepted in Agronomic crops (Springer-nature Publication).

12. Bhatt, R., Kaur, R. and Gosh, A. (2018c). Strategies to practice climate smart agriculture to improve the livelihoods under rice-wheat systems in South Asia. Accepted in "Sustainable Soil and Environmental Management" (Springer publication).

13.Bhatt, R., Kukal, S. S., Busari, M.A., Arora, S. and Yadav, M. (2016). Sustainability issues on rice-wheat cropping system. International Soil Water Conser Res., 4: 68-83.

14.Bhuiyan, S. I., Sattar, M. A. and Khan, M. A. K. (1995). Improving water use efficiency in rice irrigation through wet seeding. Irrig Sci., 16: 1-8. DOI:10.1007/BF00208389

15.Bouman, B. A. M. and Tuong, T. P. (2001). Field water management to save water and increase its productivity in irrigated rice. Agri Water Manage., 49: 11-30.

16.Brar, A.S., Mahal, S.S., Buttar, G.S. and Deol, J.S. (2011). Water productivity, economics and energetics of basmati rice (Oryza sativa)-wheat (Triticum aestivum) under different methods of crop establishment. Indian J Agron., 56: 317-320.

17.Dawe, D. (2005). Increasing water productivity in rice -based systems in Asia, past trends, current problems, and future prospects. Plant Prod Sci., 8: 221 30. DOI:10. 1626/pps.8.221.

18.Dhillon, B.S., Kataria, P. and Dhillon, P.K. (2010). National food security vis-à-vis sustainability of agriculture in high crop productivity regions. Curr Sci., 98: 33-36.

19.Gao, X.P., Zou, C.Q., Fan, X.Y., Zhang, F.S. and 
Hoffland, E. (2006). From flooded to aerobic conditions in rice cultivation: consequences for zinc uptake. Plant Soil., 280: 41- 47.

20.Gupta, R. and Seth, A. (2007). A review of resource conserving technologies for sustainable management of the rice-wheat cropping systems of the IndoGangetic Plains (IGP). Crop Prot., 26: 436-47.

21.Hira, G.S., Gupta, P.K. and Josan, A.S. (1998). Waterlogging Causes and Remedial Measures in SouthWest Punjab. Research Bulletin No. 1/98. Department of Soils, Punjab Agricultural University, Ludhiana.

22. Hossain, A. and Bhatt, R. (2019). intervention of climate smart technologies for improving water productivity in an enormous water use rice-wheat system of South-Asia. International letters of Natural Sci., 75: 27-35. DOI:10.18052/www.scipress.com/ ILNS.75.27

23.Hukkeri, S.B. and Sharma, A.K. (1980). Water use efficiency of transplanted and direct sown rice after different water management practices. Ind J Agric Sci., 50: 240-43.

24.Humphreys, E., Kukal, S.S., Christen, E.W., Hira, G.S., Singh, B., Yadav, S. and Sharma, R.K. (2010). Halting the groundwater decline in north-west Indiawhich crop technologies will be winners? Adv Agron., 109: 156-99.

25.IRRI. (2006). Bringing hope, improving lives: Strategic Plan2007-2015. Manila (Philippines). $61 \mathrm{p}$.

26.Jain, A.K. and Kumar, R. (2007). Water management issues-Punjab, North-West India. Proc paper In: Indo-US Workshop on Innovative E-technologies for Distance Education and Extension/Outreach for Efficient Water Management. ICRISAT, Hyderabad.

27.Jalota, S.K. and Arora, V.K.(2002). Model-based assessment of water balance components under different cropping systems in north-west India. Agric Water Manage., 57: 75-87.

28.Jat, M. L., Gathala, M.K., Ladha, J.K., Saharawat, Y.S., Jat, A.S., Vipin, Kumar., Sharma, S.K., Kumar, V. and Gupta, R. K. (2009). Evaluation of precision land leveling and double zero-till systems in the ricewheat rotation: Water use, productivity, profitability and soil physical properties. Soil Till Res.,105:112-21

29.Jat, M. L., Gupta, R., Saharawat, Y.S. and Khosla, R. (2011). Layering Precision Land Leveling and Furrow Irrigated Raised Bed Planting: Productivity and Input Use Efficiency of Irrigated Bread Wheat in Indo-Gangetic Plains. American J Plant Sci.,2:578-88

30.Jat, M.L., Chandna, P., Gupta, R., Sharma, S.K. and Gill, M.A. (2006). Laser Land Leveling: A Precursor Technology for Resource Conservation. Rice-Wheat Consortium Technical Bulletin Series 7. New Delhi: Rice-Wheat Consortium for the Indo-Gangetic Plains.

31.Jat, M.L., Pal, S.S., Subba Rao, A.V.M. and Sharma, S.K. (2003). Improving resource use efficiency in wheat through laser land leveling in an ustochrept of Indo-Gangetic plain. In: National Seminar on Developments in Soil Science, 68th Annual Convention of the Indian Society of Soil Science, November 48,2003, CSAUAT, Kanpur (UP).

32.Kahlown, M.A., Azam, M. and Kemper, W.D. (2002). Soil management strategies for rice-wheat rotations in Pakistan's Punjab. J Soil Water Conser., 61:40-44

33. Kukal SS, Hira GS, Sidhu AS (2005) Soil matric potential-based irrigation scheduling to rice (Oryza sativa). Irrigation Science 23, 153-159.
34.Kukal, S.S. and Aggarwal, G.C. (2003a) Puddling depth and intensity effects in rice-wheat system on a sandy loam soil. I. Development of subsurface compaction. Soil Till Res., 72:1-8.

35.Kukal, S.S. and Aggarwal, G.C. (2003b). Puddling depth and intensity effects in rice-wheat system on a sandy loam soil II. Water use and crop performance. Soil Till Res., 74: 37-45.

36.Kukal, S.S., Singh, Y., Yadav, S., Humphreys, E., Kaur, A. and Thaman, S. (2008). Why grain yield of transplanted rice on permanent raised beds declines with time? Soil Till Res., 99: 261-267.

37.Kukal, S.S., Yadav S., Humphreys, E., Kaur, A., Singh, Y., Thaman, S., Singh, V. and Timsinac, J. (2010). Factors affecting irrigation water savings in raised beds in rice and wheat. Field Crop Res., 118: 43-50.

38.Minhas, P.S., Jalota, S.K., Arora, V.K., Jain, A.K., Vashist, K.K., Choudhary, O.P., Kukal, S.S. and Vashisht, B.B. (2010). Managing water resources for ensuing sustainable agriculture: Situational analysis and options for Punjab. Research Bulletin. Directorate of Research, Punjab Agricultural University, Ludhiana.

39.Pal, S.S., Jat, M.L. and Subba Rao, A.V.M. (2003). Laser land leveling for improving water productivity in rice-wheat system. PDCSR Newsletter

40.Prihar, S.S., Arora, V.K. and Jalota, S.K. (2010). Enhancing crop water productivity to ameliorate groundwater decline. Curr Sci., 99: 588-93.

41.Rao, A.N., Johnson, D.E., Sivaprasad, B., Ladha, J.K. and Mortimer, A.M. (2007). Weed management in direct-seeded rice. Adv. Agron., 93, 153-255.

42.Rashid, M.H., Alam, M.M., Khan, M. A.H. and Ladha, J.K. (2009). Productivity and resource use of direct(drum)-seeded and transplanted rice in puddled soils in rice-rice and rice-wheat ecosystem. Field Crops Res., 113: 274-281. DOI: 10.1016/j.fcr.2009.06.004.

43.Rickman, J.F. (2002). Manual for laser land leveling, Rice-wheat Consortium Technical Bulletin Series 5. New Delhi-12, India: Rice-wheat Consortium for the Indo-Gangetic Plains. pp. 24.

44.Sattar, A., Khan. F.H. and Tahir, A.R. (2003). Impact of precision land leveling on water saving and drainage requirement. $J$ AMA., 34: 39- 41.

45.Singh, Y., Singh, G., Johnson, D. and Mortimer, M. (2005). Changing from transplanted rice to direct seeding in the rice-wheat cropping system in India. In: Rice is Life: Scientific Perspectives for the 21st Century, Tsukuba, Japan: Proceedings of the World Rice Research Conference, 4-7 November 2004, pp. 198-201.

46.Soni, V. (2012). Groundwater loss in India and an integrated climate solution. Curr Sci., 102(8):10982001

47.Sudhir-Yadav., Gill, G., Humphreys, E., Kukal, S.S. and Walia, U.S. (2011a). Effect of water management on dry seeded and puddle transplanted rice. Part-1 Crop performance. Field Crop Res., 120: 112-122.

48.Sudhir-Yadav., Humphreys, E., Kukal, S.S., Gill, G. and Rangarajan, R. (2011b). Effect of water management on dry seeded and puddled transplanted rice. Part-2 Water balance and water productivity. Field Crop Res., 120: 123-132.

49.Sur, H.S., Prihar, S.S. and Jalota, S.K. (1981). Effect of rice-wheat and maize-wheat rotations on water transmission and wheat root development in a sandy 
Saini, J. and Bhatt, R. / J. Appl. \& Nat. Sci. 11(3): 698- 703 (2019)

loam of the Punjab, India. Soil Till Res., 1: 361-371.

50.Tuong, T. P. (1999). Productive water use in rice production, Opportunities and limitations. J Crop Prod 2: 241-64.

51.Tuong, T.P., Pablico, P.P., Yamauchi, M., Confesor, R. and Moody, K. (2000). Increasing water productivity and weed suppression of wet seeded rice: effect of water management and rice genotypes. J. Exp. Agric., 36: 1-19.

52.Tyagi, S. K., Datta, P. S. and Singh, R. (2012). Need for proper water management for food security. Curr Sci., 105: 690-695.

53.Wallace, J.S. and Gregory, P.J. (2002). Water resources and their use in food production. Aq Sci., 64: 363-375.
54.Yadav, M., Tripathi J, Rawal N, Yadav B.P, McDonald, A., Humphreys, E. Yadav, S., Devkota, K., Bhatt, R. and Marasini, M. (2015). Direct Seeded Rice Productivity as Influenced by Establishment Methods, Seed Rate and Weed Management. Pp 347-352 IN Proceedings of the 28th National Summer Crops Workshop. 17-18 March 2015. Published by Government of Nepal, Nepal Agricultural Research Council. ISBN: 978-9937-0-3554-5, NPSN: 00578391/2017/18.

55.Yadav, M., Tripathi J., Bhatt R. and Rawal, N. (2018). Tensiometer based irrigation scheduling in wheat for improved water use efficiency in Nepal. J Soil Water Conser., 17(3): 275-279. DOI: 10.5958/24557145.2018.00040.1 